\title{
Probiotik pada Gangguan Saluran Cerna Fungsional
}

Valerie Andrea, ${ }^{*}$ Badriul Hegar**

${ }^{*}$ Rumah Sakit Umum Daerah Dr. Dradjat Prawiranegara, Banten

${ }^{* *}$ Departemen Ilmu Kesehatan Anak Fakultas Kedokteran Universitas Indonesia Rumah Sakit Dr. Cipto Mangunkusumo, Jakarta

Probiotik memiliki kemampuan untuk memengaruhi komposisi mikroflora saluran cerna. Ketika dikonsumsi dalam jumlah adekuat, probiotik memiliki efek positif terhadap kesehatan pejamu. Terdapat beberapa penelitian yang menilai efek terapeutik probiotik terhadap berbagai macam penyakit, termasuk gangguan saluran cerna fungsional pada anak. Gangguan saluran cerna fungsional adalah gangguan yang dianggap terkait dengan saluran cerna, namun tidak dapat dijelaskan oleh kelainan struktural maupun biokimia. Penelitian besar menggunakan probiotik pada gangguan saluran cerna fungsional telah banyak dilakukan. Penggunaan probiotik juga dianggap aman dan hampir tidak pernah dilaporkan efek samping pada rawat jalan. Beragam strain, dosis, dan metodelogi penelitian menjadikan kesulitan dalam menerjemahkan dan menyimpulkan secara keseluruhan hasil penelitian yang ada. Walaupun demikian, beberapa penelitian dengan metodelogi yang baik memperlihatkan fakta bahwa peran probiotik terhadap beberapa gangguan saluran cerna fungsional tidak dapat diabaikan. Sari Pediatri 2018;20(3):185-9

Kata kunci: probiotik, gangguan saluran cerna fungsional, nyeri perut fungsional, konstipasi fungsional, kolik infantil

\section{Probiotics in Functional Gastrointestinal Disorders}

Valerie Andrea, Badriul Hegar

Probiotics have the ability to affect the compositioin of gastrointestinal microflora. When consumed in adequate amounts, probiotics have a positive effect on the health of the host. There have been several studies investigating the therapeutic effects of probiotics on various disease, including functional gastrointestinal disorders in children. Functional gastrointestinal disorders are disorders that are considered to be related to the gastrointestinal tract, but cannot be explained by structural or biochemical abnormalities. Large studies using probiotics in functional gastrointestinal disorders have been widely carried out. The use of probiotics is also considered safe and side-effects in ambulatory care have almost not been reported. It is difficult to translate and summarize heterogeneous-based study results, which are mainly due to various strains, doses and research methodologies. However, several good methodological studies show the fact that the role of probiotics in some functional gastrointestinal disorders cannot be ignored. Sari Pediatri 2018;20(3):185-9

Keywords: probiotics, functional gastrointestinal disorders, functional abdominal pain, functional constipation, infantile colic

Alamat korespondensi: Badriul Hegar. Departemen Ilmu Kesehatan Anak Fakultas Kedokteran Universitas Indonesia, Rumah Sakit Dr. Cipto Mangunkusumo Jakarta, Jl. Salemba 6 Jakarta Pusat, E-mail : hegarsyarif21959@gmail.com 
Valerie Andrea dkk: Probiotik pada gangguan saluran cerna fungsional

$G$

angguan saluran cerna fungsional adalah gangguan yang dianggap terkait dengan saluran cerna, tetapi tidak dapat dijelaskan oleh kelainan struktural maupun biokimia. Diagnosis gangguan saluran cerna fungsional ditegakkan berdasarkan gejala klinis dengan menggunakan Rome Criteria $I V^{1}$ yang dibedakan menjadi 2 kelompok berdasarkan usia anak, yaitu 1) gangguan saluran cerna fungsional pada neonatus/ balita dan 2) gangguan saluran cerna fungsional pada anak/remaja. ${ }^{1}$ Gangguan saluran cerna fungsional pada neonatus/balita mencakup regurgitasi infantil, sindrom ruminasi infantil, sindrom muntah siklik, kolik infantil, diare fungsional, dyschezia infantil, dan konstipasi fungsional. ${ }^{2}$ Sedangkan, gangguan saluran cerna fungsional pada anak/remaja meliputi gangguan mual dan muntah fungsional, gangguan nyeri perut fungsional, dan gangguan defekasi fungsional. ${ }^{3}$

Saluran cerna anak dihuni oleh beragam mikroflora komensal yang merupakan sebuah ekosistem terpisah. Mikroflora saluran cerna berkontribusi terhadap nutrisi pejamu, regulasi angiogenesis saluran cerna, perlindungan dari kuman patogen, dan pembentukan respon imun. ${ }^{4}$ Probiotik sendiri didefinisikan sebagai mikroorganisme hidup non patogen ketika dikonsumsi dalam jumlah adekuat, memiliki efek positif terhadap kesehatan pejamu. Peran probiotik terhadap kesehatan saluran cerna anak merupakan topik yang banyak dibicarakan dan menjadi kajian para ahli. Beberapa penelitian menilai efek terapeutik probiotik terhadap berbagai macam penyakit, termasuk gangguan saluran cerna fungsional pada anak. ${ }^{1}$ Kajian mengenai mekanisme kerja strain mikroflora dan uji klinis merupakan tahapan yang wajib dilakukan untuk menilai efektivitas dari probiotik. Efek in vitro dari suatu strain dapat menampilkan perilaku yang berbeda saat dilakukan penilaian secara in vivo. ${ }^{5}$ Begitu pula efek dari satu strain tidak dapat diekstrapolasikan ke strain lain, meskipun mereka berasal dari spesies yang sama.

Probiotik dengan data bukti ilmiah kuat yang dapat direkomendasikan untuk penggunaan di bidang kesehatan atau kedokteran. Beberapa produk merupakan kombinasi dari strain yang berbeda, sehingga kombinasi tersebut harus melalui tahapan uji klinis karena mungkin memiliki efek yang sinergis atau kontradiktif. Dosis dan durasi pemberian juga harus diperhitungkan karena dosis dan durasi yang berbeda mungkin dapat memiliki efek yang berlawanan. ${ }^{6}$ Pada tulisan ini akan diperlihatkan beberapa data penggunaan probiotik pada gangguan saluran cerna fungsional yang sering ditemukan, yaitu nyeri perut fungsional, konstipasi fungsional dan kolik infantil.

\section{Nyeri perut fungsional}

Pada Rome Criteria IV istilah "abdominal pain related functional gastrointestinal disorders" diubah menjadi "functional abdominal pain disorders" (nyeri perut fungsional). Salah satu tipe dari nyeri perut fungsional adalah irritable bowel syndrome (IBS). Kriteria diagnostik untuk IBS harus meliputi seluruh hal berikut: 1) nyeri perut paling tidak 4 hari per bulan terkait dengan satu atau lebih dari berikut: a) berkaitan dengan defekasi, b) perubahan frekuensi buang air besar, c) perubahan bentuk tinja; 2) pada anak dengan konstipasi, nyeri tidak membaik dengan perbaikan konstipasi; 3) setelah evaluasi yang tepat, gejala tidak dapat dijelaskan sepenuhnya dengan kondisi medis lain. Kriteria tersebut terpenuhi paling tidak dua bulan sebelum diagnosis.

Data efektivitas penggunaan probiotik terhadap IBS pada anak sangat terbatas. Sebuah review Cochrane dari tahun 2009 mencatat efek terbatas dari Lactobacillus terhadap perbaikan gejala klinis dibandingkan dengan plasebo (OR 1,17 (95\% CI 0,62-2,21)). ${ }^{7}$ Sebuah uji acak selama 6 minggu membandingkan efektivitas Lactobacillus $G G$ (LGG) dengan plasebo pada anak yang mengalami IBS menunjukkan hasil bahwa LGG tidak lebih baik dibandingkan dengan plasebo dalam mengurangi nyeri perut, meskipun didapatkan kejadian distensi abdomen yang lebih rendah pada kelompok LGG. ${ }^{8}$ Penelitian lain memperlihatkan bahwa LGG menurunkan frekuensi dan tingkat keparahan nyeri perut secara bermakna dibandingkan dengan data awal. Selain itu, jumlah pasien dengan hasil pemeriksaan permeabilitas usus yang tidak normal juga menurun secara bermakna setelah mendapat LGG. ${ }^{9}$ Sebuah metaanalisis menunjukkan bahwa dibandingkan dengan plasebo, suplementasi LGG memberikan tingkat respons pengobatan yang lebih tinggi secara bermakna pada keseluruhan populasi dengan nyeri perut fungsional dan populasi subkelompok IBS. ${ }^{10}$

Uji silang acak menggunakan VSL\#3 dan plasebo pada anak dan remaja yang mengalami IBS selama 6 minggu menunjukkan efek superior dari VSL\#3 dibandingkan dengan plasebo dalam meringankan gejala, meringankan nyeri perut dan kembung, serta dalam penilaian keluarga terhadap gangguan 
aktivitas sehari-hari. Tidak ditemukan perbedaan bermakna pada pola tinja. ${ }^{11}$ Berdasarkan sebuah uji silang didapatkan bahwa pada anak dengan IBS, campuran probiotik Bifidobacterium infantis $M-36$, Bifidobacterium breve $M-1 \sigma \mathrm{V}$ dan Bifidobacterium longum BB536 dikaitkan dengan berkurangnya nyeri perut dan meningkatnya kualitas hidup. ${ }^{12}$

\section{Konstipasi fungsional}

Konstipasi merupakan masalah yang sering terjadi pada anak. Kriteria diagnostik untuk konstipasi fungsional menurut Rome Criteria IV harus mencakup dua atau lebih dari hal-hal berikut yang terjadi setidaknya satu kali per minggu selama minimal 1 bulan dengan kriteria yang tidak memenuhi untuk diagnosis IBS. Hal-hal tersebut meliputi: 1) dua atau kurang buang air besar di toilet per minggu pada anak usia perkembangan minimal 4 tahun, 2) paling tidak satu episode inkontinensia tinja per minggu, 3) riwayat postur retentif atau retensi tinja yang berlebihan, 4) riwayat gerakan usus yang nyeri atau keras, 5) terdapat massa tinja yang besar di rektum, 6) riwayat tinja berdiameter besar yang dapat menghambat toilet. Diagnosis konstipasi fungsional ditegakkan apabila setelah evalausi yang tepat, gejala tidak dapat dijelaskan dengan kondisi medis lain. ${ }^{3}$

Probiotik diasumsikan memiliki pengaruh positif terhadap mikroflora saluran cerna dengan efek pada konsistensi tinja dan frekuensi buang air besar. Walaupun demikian, tidak sedikit dari penelitian yang ada menunjukkan hasil kontradiktif. Sebuah uji terbuka memperlihatkan efek Bifidobactrium breve terhadap peningkatan frekuensi buang air besar pada anak dengan konstipasi fungsional. Selain itu, $B$. breve juga memiliki efek positif terhadap konsistensi tinja, menurunkan episode inkontinensia tinja, dan mengurangi nyeri perut. ${ }^{13}$

Pada uji terbuka lainnya, pemberian kombinasi probiotik B. bifidum, B. infantis, B. longum, L. casei, $L$. plantarum, dan $L$. rhamnosus memperbaiki gejala konstipasi. ${ }^{14}$ L. casei rhamnosus Lcr35 juga dilaporkan memberikan hasil yang efektif pada tata laksana anak dengan konstipasi kronik. Pasien yang mendapatkan Lcr35 memiliki frekuensi buang air besar yang lebih tinggi dan tinja yang lebih lunak dibandingkan dengan kelompok plasebo. ${ }^{15}$ Begitu pula dengan $L$. reuteri (DSM 17938) memiliki efek positif terhadap peristaltik bayi yang mengalami konstipasi kronik, meski tidak ada perbaikan pada konsistensi tinja dan episode menangis. ${ }^{16}$ Yogurt yang dilengkapi dengan $B$. longum memberikan efek positif terhadap frekuensi buang air besar. ${ }^{17}$

Hasil yang tidak efektif terlihat pada pemberian $B$. lactis terhadap anak yang mengalami konstipasi., ${ }^{5,6}$ Meskipun pemberian susu formula yang mengandung B. lactis strain DN-173010 dapat meningkatkan frekuensi buang air besar pada anak yang mengalami konstipasi, tetapi peningkatan tersebut tidak berbeda bermakna dengan kelompok kontrol. ${ }^{18}$ Pemberian probiotik untuk anak yang mengalami konstipasi fungsional masih memerlukan dukungan penelitian acak terkontrol yang dirancang dengan baik. ${ }^{19}$ Dengan makin banyaknya data yang tersedia, akan memudahkan para ahli mengkajinya untuk mempertimbangan sebagai sebuah rekomendasi. Oleh karena itu, probiotik masih termasuk produk kajian dalam tata laksana konstipasi pada anak. ${ }^{20}$

\section{Kolik infantil}

Kolik infantil sering terjadi pada bayi di bawah usia 5 bulan yang menyebabkan orang tua putus asa dalam mengatasinya. Kolik infantil digambarkan sebagai sindrom perilaku pada bayi usia 1-4 bulan yang melibatkan periode panjang menangis dan perilaku sulit untuk ditenangkan. Tangisan bayi terjadi tanpa penyebab yang jelas, sehingga sifat alami mereka yang tidak dapat dijelaskan merupakan salah satu alasan utama kekhawatiran pengasuh. Berdasarkan Rome Criteria IV, diagnosis kolik infantil ditegakkan apabila terdapat seluruh hal berikut: 1 ) bayi berusia $<5$ bulan ketika gejala muncul dan menghilang, 2) periode bayi menangis, rewel, atau iritabilitas berulang dan panjang dilaporkan oleh pengasuh yang terjadi tanpa penyebab yang jelas dan tidak dapat dicegah atau diselesaikan oleh pengasuh, 3) tidak ada bukti bayi gagal tumbuh, demam, atau sakit. ${ }^{2}$

Data penggunaan probiotik untuk kolik infantil juga sangat terbatas. L. reuteri telah dikaji secara mendalam pada bayi kolik infantil yang mendapat ASI. Pemberian tersebut memperbaiki gejala klinis kolik infantil. ${ }^{21-23}$ Namun, tidak ada data L. reuteri pada bayi yang mendapat susu formula. Dupont et al melaporkan efikasi strain probiotik lain pada bayi yang mendapat susu formula. ${ }^{24}$ 
Valerie Andrea dkk: Probiotik pada gangguan saluran cerna fungsional

\section{Keamanan}

Probiotik memiliki banyak data mengenai keamanannya, terutama terkait Lactobacilli dan Bifidobacteria. ${ }^{25}$ Setiap probiotik memiliki risiko, khususnya dalam konteks kerentanan pejamu. ${ }^{26}$ Probiotik "dianggap aman" dan hampir tidak pernah dilaporkan efek samping pada rawat jalan. Infeksi invasif pada bayi dan anak sangat jarang. ${ }^{27-29}$ Secara klinis mungkin dapat terjadi transfer plasmid resistensi antibiotik. Penggunaan probiotik jangka panjang dengan seleksi antibiotik yang ketat dapat menyebabkan resistensi antibotik, dan gen resisten dapat dipindahkan ke bakteri lain. ${ }^{30}$ Potensi memindahkan resistensi antibiotik tampaknya rendah dengan produk probiotik yang tersedia saat ini. ${ }^{25}$

Translokasi bakteri dari saluran cerna ke dalam sirkulasi darah sistemik belum pernah dilaporkan. Suplementasi probiotik harus hati-hati terutama pada anak dengan kondisi berpotensi mengalami gangguan integritas mukosa saluran cerna. ${ }^{31}$ Strain harus menjadi pertimbangan dalam menilai keamanan. ${ }^{25}$ Suplementasi probiotik harus mempertimbangkan keuntungan yang diperoleh dan risiko terjadinya infeksi invasif.

\section{Kesimpulan}

Probiotik memiliki kemampuan untuk memengaruhi komposisi mikroflora saluran cerna. Meskipun penelitian dengan skala besar telah banyak dilakukan begitu pula pemberian probiotik tampaknya aman, tetapi indikasi yang jelas apalagi rekomendasi penggunaannya masih sangat terbatas. Beragam strain, dosis, dan metodologi penelitian menjadikan kesulitan dalam menerjemahkan dan menyimpulkan secara keseluruhan hasil penelitian yang ada. Walaupun demikian, beberapa penelitian dengan metodologi yang baik memperlihatkan fakta bahwa peran probiotik terhadap beberapa gangguan saluran cerna fungsional tidak dapat diabaikan.

\section{Daftar pustaka}

1. Koppen IJN, Nurko S, Saps M, Lorenzo CD, Benninga MA. The pediatric rome IV criteria: what's new?. Expert Rev Gastroenterol Hepatol 2017;11(3):193-201.

2. Benninga MA, Nurko S, Faure C, Hyman PE, Roberts ISJ,
Schechter NL. Childhood functional gastrointestinal disorders: neonate/toddler. Gastroenterology 2016;150:1443-55.

3. Hyams JS, Lorenzo CD, Saps M, Shulman RJ, Statiano A, Van Tilburg M. Childhood functional gastrointestinal disorders: child/adolescent. Gastroenterology 2016;150:1456-68.

4. Johnson CL, Versalovic J. The human microbiome and its potential importance to pediatrics. Pediatrics 2012;129:95060.

5. Ibnou-Zekri N, Blum S, Schiffrin EJ, von der Weid T. Divergent patterns of colonization and immune response elicited from two intestinal Lactobacillus strains that display similar properties in vitro. Infect Immun 2003;71:428-36.

6. Ritchie ML, Romanuk TN. A meta-analysis of probiotic efficacy for gastrointestinal diseases. Plos One 2012;7:e34938.

7. Huertas-Ceballos AA, Logan S, Bennett C, Macarthur C. Dietary interventions for recurrent abdominal pain (RAP) and irritable bowel syndrome (IBS) in childhood. Cochrane Database Syst Rev 2009;(1):CD003019.

8. Bausserman M, Michail S. The use of Lactobacillus GG in irritable bowel syndrome in children: a double-blind randomized control trial. J Pediatr 2005;147:197-201.

9. Francavilla R, Miniello V, Magistà AM, De Canio A, Bucci N, Gagliardi F, Lionetti E, Castellaneta S, Polimeno L, Peccarisi L, Indrio F, Cavallo L. A randomized controlled trial of Lactobacillus GG in children with functional abdominal pain. Pediatrics 2010;126:e1445-152.

10. Horvath A, Dziechciarz P, Szajewska H. Meta-analysis: Lactobacillus rhamnosus GG for abdominal pain-related functional gastrointestinal disorders in childhood. Aliment Pharmacol Ther 2011;33:1302-10.

11. Guandalini $S$, Magazzù $G$, Chiaro A, La Balestra V, Di Nardo G, Gopalan S, Sibal A, Romano C, Canani RB, Lionetti P, Setty M. VSL\#3 improves symptoms in children with irritable bowel syndrome: a multicenter, randomized, placebo-controlled, double-blind, crossover study. J Pediatr Gastroenterol Nutr 2010, 51:24-30.

12. Giannetti E, Maglione M, Alessandrella A, dkk. A mixture of 3 bifidobacteria decreases abdominal pain and improves the quality of life in children with irritable bowel syndrome: a multicenter, randomized, double-blind, placebo-controlled, crossover trial. J Clin Gastroenterol 2017;51(1):e5-210.

13. Tabbers MM, de Milliano I, Roseboom MG, Benninga MA. Is Bifidobacterium breve effective in the treatment of childhood constipation? Results from a pilot study. Nutr J 2011;10:19.

14. Bekkali NL, Bongers ME, Van den Berg MM, Liem O, Benninga MA. The role of a probiotics mixture in the treatment of childhood constipation: a pilot study. Nutr J 2007;6:17.

15. Bu LN, Chang MH, Ni YH, Chen HL, Cheng CC. 
Lactobacillus casei rhamnosus Lcr35 in children with chronic constipation. Pediatr Int 2007;49:485-90.

16. Coccorullo P, Strisciuglio C, Martinelli M, Miele E, Greco L, Staiano A. Lactobacillus reuteri (DSM 17938) in infants with functional chronic constipation: a double-blind, randomized, placebo-controlled study. J Pediatr 2010;157:598-602.

17. Guerra PV, Lima LN, Souza TC, Mazochi V, Penna FJ, Silva AM, Nicoli JR, Guimarães EV. Pediatric functional constipation treatment with Bifidobacterium-containing yogurt: a crossover, double-blind, controlled trial. World J Gastroenterol 2011;17:3916-21.

18. Tabbers MM, Chmielewska A, Roseboom MG, Crastes N, Perrin C, Reitsma JB, Norbruis O, Szajewska H, Benninga MA. Fermented milk containing Bifidobacterium lactis DN173010 in childhood constipation: a randomized, doubleblind, controlled trial. Pediatrics 2011;127:e1392-99.

19. Tabbers MM, Boluyt N, Berger MY, Benninga MA. Nonpharmacologic treatments for childhood constipation: systematic review. Pediatrics 2011;128:753-61.

20. Chmielewska A, Szajewska H. Systematic review of randomised controlled trials: probiotics for functional constipation. World J Gastroenterol 2010;16:69-75.

21. Savino F, Pelle E, Palumeri E, Oggero R, Miniero R. Lactobacillus reuteri (American Type Culture Collection Strain 55730) versus simethicone in the treatment of infantile colic: a prospective randomized study. Pediatrics 2007;119:e124-30.

22. Savino F, Cordisco L, Tarasco V, Palumeri E, Calabrese R, Oggero R, Roos S, Matteuzzi D. Lactobacillus reuteri DSM 17938 in infantile colic: a randomized, double-blind, placebocontrolled trial. Pediatrics 2010;126:e526-33.
23. Szajewska H, Gyrczuk E, Horvath A. Lactobacillus reuteri DSM 17938 for the management of infantile colic in breastfed infants: a randomized, double-blind, placebo-controlled trial. J Pediatr 2013;162:256-62.

24. Dupont C, Rivero M, Grillon C, Belaroussi N, Kalindjian A, Marin V. Alpha-lactalbumin-enriched and probioticsupplemented infant formula in infants with colic: growth and gastrointestinal tolerance. Eur J Clin Nutr 2010;64:765-7.

25. Shanahan F. A commentary on the safety of probiotics. Gastroenterol Clin North Am 2012;41:869-76.

26. Fedorak RN, Madsen KI. Probiotics and prebiotics in gastrointestinal disorders. Curr Opin Gastroenterol 2004;20:146-55.

27. Borriello SP, Hammes WP, Holzapfel W, Marteau P, Schrezenmeir J, Vaara M, Valtonen V. Safety of probiotics that contain Lactobacilli or Bifidobacteria. Clin Infect Dis 2003;36:775-780.

28. Mackay AD, Taylor MB, Kibbler CC, Hamilton-Miller JM. Lactobacillus endocarditis caused by a probiotics organism. Clin Microbiol Infect 1999;5:290-2.

29. Rautio M, Jousimies-Somer H, Kauma H, Pietarinen I, Saxelin M, Tynkkynen S, Koskela M. Liver abcess due to a Lactobacillus rhamnosus strain indistinguishable from a $\mathrm{L}$. rhamnosus strain GG. Clin Infect Dis 1999;28:1159-60.

30. Dai M, Lu J, Wang Y, Liu Z, Yuan Z. In vitro development and transfer of resistance to chlortetracycline in Bacillus subtilis. J Microbiol 2012;50:807-12.

31. Weichert S, Schroten H, Adam R. The role of prebiotics and probiotics in prevention and treatment of childhood infectious diseases. Pediatr Infect Dis J 2012;31:856-62 